\title{
Front Matter: Volume 9406
}

, "Front Matter: Volume 9406," Proc. SPIE 9406, Intelligent Robots and Computer Vision XXXII: Algorithms and Techniques, 940601 (8 February 2015); doi: 10.1117/12.2185644

EPIE Event: SPIE/IS\&T Electronic Imaging, 2015, San Francisco, California, United SPIE. States 
PROCEEDINGS

IS\&T ELECTRONIC

SPIE. IMAGING

\section{Intelligent Robots and Computer Vision XXXII: Algorithms and Techniques}

Juha Röning

David Casasent

Editors

9-10 February 2015

San Francisco, California, United States

Sponsored by

IS\&T-The Society for Imaging Science and Technology

SPIE

Published by

SPIE 
The papers included in this volume were part of the technical conference cited on the cover and title page. Papers were selected and subject to review by the editors and conference program committee. Some conference presentations may not be available for publication. The papers published in these proceedings reflect the work and thoughts of the authors and are published herein as submitted. The publishers are not responsible for the validity of the information or for any outcomes resulting from reliance thereon.

Please use the following format to cite material from this book:

Author(s), "Title of Paper," in Intelligent Robots and Computer Vision XXXII: Algorithms and Techniques, edited by Juha Röning, David Casasent, Proceedings of SPIE-IS\&T Electronic Imaging, SPIE-IS\&T Vol. 9406, Article CID Number (2015)

ISSN: 0277-786X

ISBN: 9781628414967

Copublished by

SPIE

P.O. Box 10, Bellingham, Washington 98227-0010 USA

Telephone +1 3606763290 (Pacific Time) · Fax +1 3606471445

SPIE.org

and

IS\&T-The Society for Imaging Science and Technology

7003 Kilworth Lane, Springfield, Virginia, 22151 USA

Telephone +1 7036429090 (Eastern Time) · Fax +1 7036429094

imaging.org

Copyright (C) 2015, Society of Photo-Optical Instrumentation Engineers and The Society for Imaging Science and Technology.

Copying of material in this book for internal or personal use, or for the internal or personal use of specific clients, beyond the fair use provisions granted by the U.S. Copyright Law is authorized by the publishers subject to payment of copying fees. The Transactional Reporting Service base fee for this volume is $\$ 18.00$ per article (or portion thereof), which should be paid directly to the Copyright Clearance Center (CCC), 222 Rosewood Drive, Danvers, MA 01923. Payment may also be made electronically through CCC Online at copyright.com. Other copying for republication, resale, advertising or promotion, or any form of systematic or multiple reproduction of any material in this book is prohibited except with permission in writing from the publisher. The CCC fee code is 0277-786X/15/\$18.00.

Printed in the United States of America.

Paper Numbering: Proceedings of SPIE follow an e-First publication model, with papers published first online and then in print. Papers are published as they are submitted and meet publication criteria. A unique citation identifier (CID) number is assigned to each article at the time of the first publication. Utilization of CIDs allows articles to be fully citable as soon as they are published online, and connects the same identifier to all online, print, and electronic versions of the publication. SPIE uses a six-digit CID article numbering system in which:

- The first four digits correspond to the SPIE volume number.

- The last two digits indicate publication order within the volume using a Base 36 numbering

system employing both numerals and letters. These two-number sets start with 00, 01, 02, 03, 04, $05,06,07,08,09,0 A, 0 B \ldots$ OZ, followed by 10-1Z, 20-2Z, etc.

The CID Number appears on each page of the manuscript. The complete citation is used on the first page, and an abbreviated version on subsequent pages. 


\title{
Contents
}

\author{
$\checkmark \quad$ Authors \\ vii Conference Committee
}

\section{SESSION 1 INTELLIGENT MOBILE ROBOT METHODS AND ADVANCEMENTS I}

940602 Synchronization of mobile robot's actuated wheels [9406-1]

940603 Moving object detection from a mobile robot using basis image matching [9406-2]

\section{SESSION 2 INTELLIGENT MOBILE ROBOT METHODS AND ADVANCEMENTS II}

940605 Thorough exploration of complex environments with a space-based potential field [9406-4]

940606 Localization using omnivision-based manifold particle filters [9406-5]

940607 An online visual loop closure detection method for indoor robotic navigation [9406-6]

940608 Improved obstacle avoidance and navigation for an autonomous ground vehicle [9406-7]

SESSION $3 \quad$ IMAGE UNDERSTANDING AND SCENE ANALYSIS

940609 Statistical approach for supervised codeword selection [9406-8]

9406 0A Multi-polarimetric textural distinctiveness for outdoor robotic saliency detection [9406-9]

9406 OB Semantic video segmentation using appearance and geometric information [9406-10]

$94060 \mathrm{C}$ Feature matching method study for uncorrected fish-eye lens image [9406-11]

SESSION 4 PATTERN RECOGNITION AND IMAGE PROCESSING FOR COMPUTER VISION AND ROBOTICS

9406 OE Graph optimized Laplacian Eigenmaps for face recognition [9406-13]

9406 OF A superfast algorithm for self-grouping of multiple objects in image plane [9406-14]

9406 OG Research on the feature set construction method for spherical stereo vision [9406-15] 
$9406 \mathrm{OH}$ Development of autonomous grasping and navigating robot [9406-16]

9406 ol Fine grained recognition of masonry walls for built heritage assessment [9406-17]

9406 0J Visual based navigation for power line inspection by using virtual environments [9406-18]

SESSION 6 3D VISION: MODELING, REPRESENTATION, PERCEPTION, PROCESSING AND RECOGNITION

9406 OK PanDAR: a wide-area, frame-rate, and full color LIDAR with foveated region using backfilling interpolation upsampling [9406-20]

9406 OL 3D object recognition based on local descriptors [9406-21]

$94060 \mathrm{M}$ The study of calibration and epipolar geometry for the stereo vision system built by fisheye lenses [9406-23]

INTERACTIVE PAPER SESSION

9406 ON Intermediate view synthesis for eye-gazing [9406-24]

940600 Increasing signal-to-noise ratio of reconstructed digital holograms by using light spatial noise portrait of camera's photosensor [9406-25]

9406 OP Camera calibration based on parallel lines [9406-26] 


\section{Authors}

Numbers in the index correspond to the last two digits of the six-digit citation identifier (CID) article numbering system used in Proceedings of SPIE. The first four digits reflect the volume number. Base 36 numbering is employed for the last two digits and indicates the order of articles within the volume. Numbers start with 00, 01, 02, 03, 04, 05, 06, 07, 08, 09, 0A, 0B...0Z, followed by 10-1Z, 20-2Z, etc.

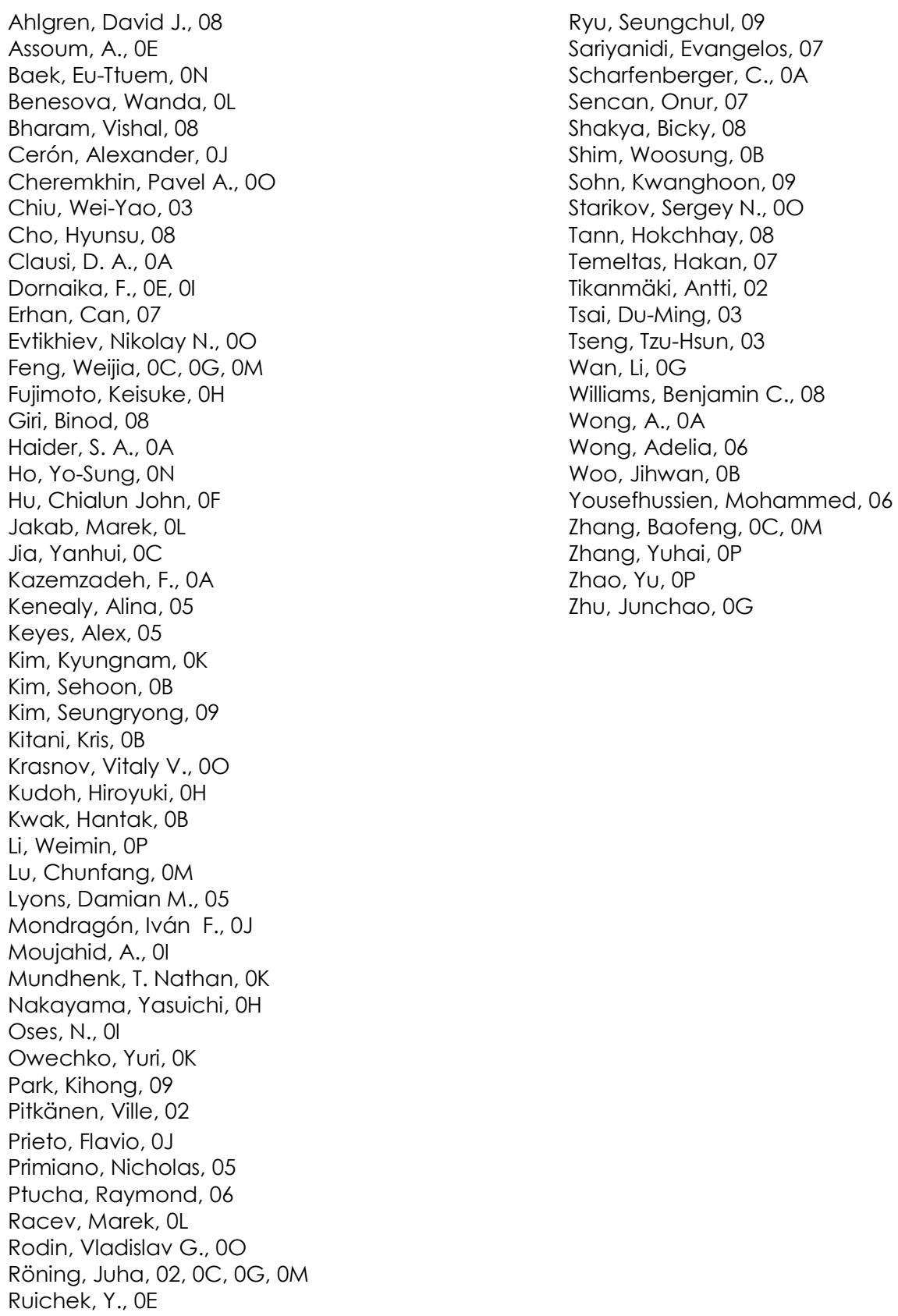

Ryu, Seungchul, 09

Sariyanidi, Evangelos, 07

Scharfenberger, C., OA

Sencan, Onur, 07

Shakya, Bicky, 08

Shim, Woosung, OB

Sohn, Kwanghoon, 09

Starikov, Sergey N., 00

Tann, Hokchhay, 08

Temeltas, Hakan, 07

Tikanmäki, Antti, 02

Tsai, Du-Ming, 03

Tseng, Tzu-Hsun, 03

Wan, Li, OG

Williams, Benjamin C., 08

Wong, A., OA

Wong, Adelia, 06

Woo, Jihwan, $O B$

Yousefhussien, Mohammed, 06

Zhang, Baofeng, OC, OM

Zhang, Yuhai, OP

Zhao, Yu, OP

Zhu, Junchao, OG 
Proc. of SPIE-IS\&T/ Vol. $9406940601-6$

Downloaded From: https://www.spiedigitallibrary.org/conference-proceedings-of-spie on 25 Apr 2023 Terms of Use: https://www.spiedigitallibrary.org/terms-of-use 


\section{Conference Committee}

Symposium Chair

Sheila S. Hemami, Northeastern University (United States)

Symposium Co-chair

Choon-Woo Kim, Inha University (Korea, Republic of)

Conference Chairs

Juha Röning, University of Oulu (Finland)

David Casasent, Carnegie Mellon University (United States)

Conference Program Committee

Dah-Jye Lee, Brigham Young University (United States)

Charles A. McPherson, Draper Laboratory (United States)

Kurt S. Niel, Upper Austria University of Applied Sciences (Austria)

Yoshihiko Nomura, Mie University (Japan)

Lucas Paletta, JOANNEUM RESEARCH Forschungsgesellschaft mbH

(Austria)

Daniel Raviv, Florida Atlantic University (United States)

Bernard L. Theisen, U.S. Army Tank Automotive Research,

Development and Engineering Center (United States)

Dili Zhang, Monotype Imaging (United States)

Session Chairs

1 Intelligent Mobile Robot Methods and Advancements I

Juha Röning, University of Oulu (Finland)

David Casasent, Carnegie Mellon University (United States)

2 Intelligent Mobile Robot Methods and Advancements II

Juha Röning, University of Oulu (Finland)

David Casasent, Carnegie Mellon University (United States)

3 Image Understanding and Scene Analysis

Kurt S. Niel, Upper Austria University of Applied Sciences (Austria)

4 Pattern Recognition and Image Processing for Computer Vision and Robotics

Lucas Paletta, JOANNEUM RESEARCH Forschungsgesellschaft mbH (Austria) 
5 Computer Vision Algorithms and Applications for Intelligent Robots Charles A. McPherson, Draper Laboratory (United States)

6 3D Vision: Modelling, Representation, Perception, Processing and Recognition

Terrell N. Mundhenk, HRL Laboratories, LLC (United States) 